аспірант кафедри освітології та інноваційної педагогіки Харківського національного педагогічного університету імені Г. С. Сковороди

ORCID:0000-0002-7959-9794

e-mail:zunshen@ukr.net

\title{
ЗМІСТ ПРОФЕСІЙНОЇ ПІДГОТОВКИ МАЙБУТНІХ УЧИТЕЛІВ МУЗИКИ В КНР ТА УКРАЇНІ
}

Анотація. У статті висвітлено нормативно-правову базу, що регулює питання підготовки майбутніх педагогів-музикантів в Україні та КНР. 3'ясовано, що в останній, окрім постановки цілей завдань і розподілу навчального часу Міністерство країни чітко регулює не лише зміст підготовки майбутніх учителів музики, а й зміст кожного навчального предмета окремо. Встановлено, що освіту педагога-музиканта, окрім педагогічних університетів, можна отримати у різних закладах освіти (коледжах, академіях, консерваторіях, інститутах та ін.). Визначено мету підготовки майбутніх учителів музики в Україні та КНР.

Досліджено, що розподіл дисциплін, спрямованих на формування загальних та професійних компетентностей, досить рівномірний як в Україні, так і в КНР. Встановлено, що відмінним у змісті підготовки майбутніх учителів музики $є$ те, що в КНР особливу увагу приділяють вивченню англійської мови, політології, філософії, історії та культури окремого регіону (залежно від місця знаходження університету), а в Україні проводиться більша кількість саме індивідуальних фахових занять. Визначено, що окрім подібної для обох країн активної педагогічної практики, $є$ й абсолютно відмінні. Так, в КНР - це необов'язкова соціальна практика, в Україні - обов'язкова «Організаційно-виховна педагогічна практика в дитячих закладах оздоровлення та відпочинку». Окреслено, що виховна робота у закладах вищої педагогічної освіти КНР та Україні теж має спільні напрями та форми.

Ключові слова: вчитель музики, навчальні дисципліни; заклади вищої педагогічної освіти.

Постановка проблеми. Зміни, що відбуваються у світі, постійно вносять корективи у розвиток професійної освіти. Першою, майже завжди зазнає змін система вищої педагогічної освіти. Зважаючи на швидкі темпи iii інформатизації, необхідно вчасно реагувати та вносити зміни у зміст підготовки майбутнього вчителя. Педагог-музикант не є виключенням, тому введення нових курсів та дисциплін за вибором, зміна та/або корекція окремих розділів програм, методів викладання $є$ неминучою. 


\section{Інноватика у вихованні. Випуск 13.Том 1. 2021.}

Аналіз останніх досліджень 3 проблеми. Еволюцію змісту підготовки майбутніх учителів музики та становлення музичнопедагогічної освіти КНР розкрито у роботах Лі Яньхуей, Лю Цзин, Чень Біні, Яо Вей та інших науковців. Дослідженнями закономірностей та принципів професійної підготовки відповідних фахівців в Україні займалися науковці Л. Беземчук, Н. Овчаренко, С. Проворова, Л. Снєдкова, М. Ткаченко.

Мета статті - порівняти зміст підготовки вчителя-музиканта (бакалавра) у вищих педагогічних закладах освіти в КНР та в Україні.

Виклад основного матеріалу дослідження. В Україні та КНР професійна підготовка майбутнього вчителя музики здійснюється у коледжах, педагогічних, національних та міжнародних непедагогічних університетах, консерваторіях, академіях та в інших закладах освіти.

Однак ми вважаємо, що найбільш повною науково-теоретично та практично-методичною підготовкою $\epsilon$ саме підготовка вчителівмузикантів педагогічними університетами. Адже саме заклади вищої педагогічні освіти (далі ЗВПО) повною мірою передбачають оволодіння студентами усіма загальними та фаховими компетентностями, що необхідні для опанування професією вчитель музики.

У процесі підготови бакалаврів музичного мистецтва університети першочергово орієнтуються на нормативно-правові документи Міністерства освіти і науки України. Так, для українських університетів це «Закон про вищу освіту» (2017), Концепція розвитку педагогічної освіти (2018), Стандарт вищої освіти за спеціальністю «Музичне мистецтво» (2019.) та інші, для КНР ключовими документами $є$ «Закон про вищу освіту» (1998), «Закон про підготовку вчителів» (2019), «Керівництво щодо викладання обов’язкового курсу «Музикознавство» (педагогічна освіта) у національних коледжах та університетах професійної підготовки студентів» (2004), «Дипломне навчання і викладання у педагогічних коледжах та університетах. План реалізації огляду та оцінки (20212025pp)», (2021) та інші. Спираючись на зазначені документи, складаються освітні програми та навчальні плани майбутніх фахівців.

В Україні при підготовці саме педагогів-музикантів керівним документом є згаданий Стандарт вищої освіти за спеціальністю «Музичне мистецтво» (2019), у якому чітко прописано загальну кількість кредитів, уточнено пропорційний поділ дисциплін, спрямованих на забезпечення загальних і фахових компетентностей, та визначено програмні результати навчання. Документом закріплено перелік усіх професій за спеціальністю 025 «Музичне мистецтво». Водночас аргументовано, що цілями програми $\epsilon$ підготовка кваліфікованих фахівців, які зможуть вирішувати проблеми практичного характеру у мистецькій сфері та забезпечення теоретичною $\mathrm{i}$ методичною готовністю. Уміння комплексно застосовувати методи педагогічної, дослідницької, музикознавчої, менеджерської та інших видів діяльності. 


\section{Інноватика у вихованні. Випуск 13.Том 1. 2021.}

Щодо КНР, то при підготовці майбутніх вчителів музичного мистецтва найперше керуються рекомендованою Міністерством освіти Навчальною програмою бакалавра (педагогічної освіти) для національних коледжів та університетів зі спеціальності «Музикознавство».(2006) Так, документ визначає цілі навчання, а саме: підготовка висококваліфікованих педагогів-музикантів, що володіють високим рівнем моралі, інтелекту, фізичної готовності; теоретичними знаннями та практичними навичками реалізації музичної освіти; володіють інноваційними освітніми технологіями. У програмі зазначено рекомендований розподіл годин обов'язкових дисциплін та дисциплін за вибором, зазначено загальну кількість кредитів, вимоги до навчання студентів. Тобто, цей документ, хоч і має свою специфіку, але загалом подібний до українського.

Однак особливість підготовки майбутніх учителів музичного мистецтва в КНР вирізняється наявністю ще двох фундаментальних документів, яким немає аналогів в Україні. Це «Керівництво щодо викладання обов'язкового курсу «Музикознавство» (педагогічна освіта) у національних коледжах та університетах професійної підготовки студентів», (2004) та «Національний стандарт якості професійної освіти бакалаврів (у двох томах)», (2018). Обидва документи відіграють важливу роль при складанні програми та оцінюванні студентів у навчальному процесі.

У першому детально описано методичні вказівки до викладання усіх фахових дисциплін, їх мету, зміст, принципи, програмні результати навчання та їх критерії оцінки. Важливо, що змінювати розподіл навчального часу кожен університет має певну автономію, а дотримання «Керівництва» має бути чітким та незмінним.

Другий документ містить зміст загальноосвітніх та фахових дисциплін 92 спеціальностей, до яких готують у закладах освіти КНР.

Тривалість навчання майбутнього вчителя музики залежить від типу навчального закладу. У КНР та в Україні існують різні освітні моделі, однак саме у вищих педагогічних закладах освіти тривалість навчання на здобуття бакалавра складає чотири роки. У студентів обох країн $\epsilon$ можливість після закінчення бакалаврату отримати ще ступінь магістра музичної освіти, відповідно, термін навчання продовжується ще на одиндва роки.

У КНР кількість саме педагогічних університетів налічує близько 40, в Україні - це показник сягає 15, кількість закладів вищої освіти, де можна отримати педагогічну освіту - набагато більше: в Україні - понад 50, в КНР - близько 100.

Як в Україні, так і в КНР майбутній учитель музики повинен отримати грунтовну теоретичну, методичну та практичну підготовку. Спільним для обох країн $є$ рівномірний розподіл загальних та фахових дисциплін.

Зміст підготовки в ЗВПО обох країн передбачає вивчення таких загальноосвітніх дисциплін: іноземна мова, політологія, філософія, рідна мова професійного спрямування, історія та культура України/Китаю й 


\section{Інноватика у вихованні. Випуск 13.Том 1. 2021.}

зарубіжна та інші обов'язкові й вибіркові предмети. Однак слід звернути увагу, що в КНР набагато більше кредитів виділяється на вивчення іноземної мови, політології та філософії.

В Україні та КНР майбутні учителі музики вивчають такі фахові дисципліни, як: педагогіка, психологія теорія музики, аналіз творів, вокал, гра на музичних інструментах, хор, диригування та інші. Специфікою підготовки майбутніх музикантів в КНР є обов'язкове оволодіння одним 3 національних музичних інструментів та вивчення саме регіональної історії та музичного мистецтва. Тобто, зміст деяких дисциплін визначається відповідно до місця розташування університету. Проте недоліком у підготовці майбутніх вчителів музики в КНР на відміну від України $є$ недостатня кількість індивідуальних занять, що спричинено нестачею професійних викладачів в університетах. Як наслідок, спостерігаємо постійне збільшення кількості здобувачів третього освітнього рівня з КНР в Україні, Росії, Білорусі та в інших країнах пострадянського простору і викладання в провідних китайських університетах здійснюється педагогами зі згаданих країн.

Процес підготовки майбутніх учителів ЗВПО КНР та України передбачає проходження педагогічної практики у школі, на якій студенти спостерігають за роботою вчителя допомагають йому, проводять уроки, організовують виховні заходи, спілкуються та грають 3 дітьми. Тривалість такої практики варіюється у різних закладах освіти.

Однак, опитування вчителів КНР ще 2013 році показали результати невдоволення тим, що близько половини навчально часу займають саме загальноосвітні теоретичні курси. 3 виходом на практику майбутні педагоги стикаються з відсутністю практичних навичок роботи з дітьми та недостатньою сформованістю фахових компетентностей (Dr. Tingjie YU, 2013),. Подібну проблему після проходження обов'язкової безперервної практики у школі виявили і у майбутніх вчителів України (2016р.), так, зокрема у Харківському національному педагогічному університеті імені Г.С. Сковороди, частковим вирішенням цієї проблеми стало впровадження проєкту з елементами дуальної освіти «Школа професійного зростання «День у школі». Щоправда, він поки що діє лише на одному факультеті, однак за умови доведеної результативності його буде впроваджено на решті факультетів, зокрема і факультеті музичної освіти (Tytarenko L. Masiuk O Smolianiuk (2020) )

Розвитку практичних навичок та вдосконаленню фахових компетентностей майбутнім педагогам-музикантам в Україні та КНР допомагає ще одна практика. В Україні вона називається «Організаційновиховна педагогічна практика в дитячих закладах оздоровлення та відпочинку». Така форма $є$ загальнообов'язковою для кожного студента. Ця практика передбачає цілодобове перебування майбутніх педагогів 3 дітьми упродовж 21 дня, але за бажанням студенти можуть ії продовжити.

У КНР існує соціальна необов'язкова практика, тобто майбутній учитель музики може проходити ії лише за власним бажанням, у вільний 


\section{Інноватика у вихованні. Випуск 13.Том 1. 2021.}

від навчання час. Ї̈ зміст повністю відтворює загальнообов'язкову, передбачає ті ж самі обов'язки. Та, усвідомлюючи ії практичну значимість, переважно студенти вдаються до проходження цієї практики, за що, отримують заохочення від викладачів університету (Калашнік, Хань Чанлян (2019).

Виховна робота у ЗВПО України та КНР передбачає активну участь студентів у житті університету: організація сезонних свят, святкування визначних для країни дат, проведення концертів, участь у різного роду конкурсах, волонтерська робота.

Висновки і перспективи подальших розвідок. Отже, такий подібний, на перший погляд, зміст підготовки майбутніх учителів музики в КНР та в України має низку відмінностей, серед яких:

різне нормативно-правове регулювання музичної освіти;

по-різному розставленні пріоритети щодо дисциплін, спрямованих на формування загальних компетентностей;

різний розподіл лекційних та практичних занять, індивідуальних занять за фахом.

Окремі аспекти досвіду підготовки вчителів музики в КНР можуть бути використані у практиці України та потребують подальшого, більш грунтовного вивчення.

\section{СПИСОК ВИКОРИСТАНИХ ДЖЕРЕЛ:}

Закон про вищу освіту (2017 p. зі змінами) URL: https://zakon.rada.gov.ua/laws/show/1556-18\#Техt. [Дата звернення 30.04.21]

Калашнік, Н., Хань Чанлян (2019). Соціальна практика як засіб формування смаку до педагогічної діяльності вчителя спортивних дисциплін (Досвід КНР) Вісник Національного університету «Чернігівський колегіум» імені Т. Г. Шевченка. Серія : Педагогічні науки. Вип. 1. СС. 67-71.

Конщепиія розвитку педагогічної освіти. (2018.) URL: https://mon.gov.ua/ua/npa/pro-zatverdzhennya-koncepciyi-rozvitkupedagogichnoyi-osviti [Дата звернення 01.0521].

Стандарт вищої освіти за спечіальністю «Музичне мистецтво». (2019) URL: https://mon.gov.ua/storage/app/media/vishcha-osvita/ zatverdzeni $\% 20$ standarty/2019/05/28/025-muzichne-mistetstvo-bakalavr. pdf [Дата звернення 01.05.21p].

Teacher Education in China: Current Situation \& Related Issues, Dr. Tingjie YU. (2013), 48 p.

Tytarenko L. Masiuk O Smolianiuk N. (2020). Pedagogical Project "School of professional growth: "A day at school" as one of the ways of forming methodical competence of students". Theory and Practice of Future Teacher's Training for Work in New Ukrainian School: monograph / Edit. I.F.Prokopenko, I.M.Trubavina. - Prague, OKTAN PRINT s.r.o., PP.463-475.

\section{普通高等学校本科专业类 教学质量国家标准 (2018). URL:}

https://jwc.jit.edu.cn/info/1189/3408.htm [Дата звернення 01.05.21] 
Інноватика у вихованні. Випуск 13.Том 1. 2021.

教育部关于印发《普通高等学校本科教育教学审核评估实施方案 (2021-2025年) 》的通知URL:

http://www.moe.gov.cn/srcsite/A11/s7057/202102/t20210205_512709.html [Дата звернення 01.05.21].

全国普通高等学校音乐学 (教师教育) 本科专业课程指导方案 (2004) URL:

http://www.moe.gov.cn/s78/A17/twys_left/moe_794/moe_624/tnull_8714.html ) [Дата звернення 01.05.21].

中华人民共和国高等教育法.

URL: http://old.moe.gov.cn//publicfiles/business/htmlfiles/moe/moe_619/200407/13 11.html [Дата звернення 01 травня 2021p.].
年最新中华人民共和国教师法【全文.
(2019)URL:

https://www.jinian.online/news/955728 [Дата звернення 01.05.21].

\section{REFERENCE}

Zakon "Pro vyshchu osvitu” (2017 r. zi zminamy) (2017) (Law on Higher Education (2017 with changes ) URL: https://zakon.rada.gov.ua/laws/show/1556-18\#Text [Data zvernennia 0.05.21] [in Ukrainian].

Kalashnik, N., Khan Chanlian (2019). Sotsialna praktyka yak zasib formuvannia smaku do pedahohichnoi diialnosti vchytelia sportyvnykh dystsyplin (Dosvid PRC) (Social practice as a means of forming a taste for pedagogical activities of teachers of sports (Experience of CPR) Visnyk Natsionalnoho universytetu "Chernihivskyi kolehium" ("Chernihiv Collegium) imeni T. H. Shevchenka. Seriia : Pedahohichni nauky. Vyp. 1. SS. 67-71. [in Ukrainian].

Kontseptsiia rozvytku pedahohichnoi osvity (2018 r.) (The concept of development of pedagogical education (2018) URL: https://mon.gov.ua/ua/npa/pro-zatverdzhennya-koncepciyi-rozvitkupedagogichnoyi -osviti [data octannoho zvernennia 01/05.21]. [in Ukrainian].

Standart vyshchoi osvity za spetsialnistiu "Muzychne mystetstvo" (2019 r.) (Standard of higher education in the specialty "Musical Art") URL: https://mon.gov.ua/storage/app/media/vishcha-osvita/zatverdzeni\%20standarty /2019/05/28/025-muzichne-mistetstvo-bakalavr.pdf [data zvernennia 01.05. 21]. [in Ukrainian].

Teacher Education in China: Current Situation \& Related Issues, Dr. Tingjie YU. 2013, 48 p.

Tytarenko, L. Masiuk, O. \& Smolianiuk, N. (2020). Pedagogical Project "School of professional growth: "A day at school" one of the ways of forming methodical competence of students". V: Theory and Practice of Future Teacher's Training for Work in New Ukrainian School: monograph / Edit. I.F.Prokopenko, I.M.Trubavina. - Prague, OKTAN PRINT s.r.o., PP.463-475. 


\section{Інноватика у вихованні. Випуск 13.Том 1. 2021.}

Putong gaodeng xue jiao benke zhuanye lei jiaoxue zhiliang guojia biaozhun (2018) (Undergraduate majors in ordinary colleges and universities National standards for teaching quality) URL: https://jwc.jit.edu.cn/info/1189/3408.htm [Data zvernennia 01.05.21]. [in Chinese].

Jiaoyu bu guanyu yinfa "putong gaodeng xue jiao benke jiaoyu jiaoxue shenhe pinggu shishi fang'an (2021-2025)" de tongzhi (The Ministry of Education issued the "Undergraduate Education and Teaching in Ordinary Colleges" Notice of Review and Evaluation Implementation Plan (2021-2025). (2021) URL: http://www.moe.gov.cn/srcsite/A11/s7057/202102/t20210205_ 512709.html. [in Chinese].

Quanguo putong gaodeng xиexiao yinyue xue (jiaoshi jiaoyu) benke zhuanye kecheng zhidao fang'an (2004) (Musicology (Teacher Education) in National Colleges and Universities Undergraduate professional course guidance program). URL: http://www.moe.gov.cn/s78/A17/twys _left/moe_794/moe_624/tnull_8714.html) [data zvernennia 01.05.21] [in Chinese].

Zhonghua renmin gongheguo gaodeng jiaoyu fa (1998) (Higher Education Law of the People's Republic of China) URL:

http://old.moe.gov.cn//publicfiles/business/htmlfiles/moe/moe_619/200407/13 11.htmlю. [in Chinese].

Nian zuixin zhonghua renmin gongheguo jiaoshi fa [quanwen]. (2019). [The latest Teachers Law of the People's Republic of China in 2019] [Full Text]. URL: https://www.jinian.online/news/955728. [in Chinese].

\section{CONTENS OF PROFESSIONAL TRAINING OF FUTURE MUSIC TEACHERS IN PRC AND UKRAINE}

Shen Tsyn $\mathrm{PhD}$ Postgraduate at the Department of Educology and Innovative Pedagogy H. S. Skovoroda Kharkiv National Pedagogical University, Kharkiv, Ukraine ORCID: 0000-0002-7959-9794 e-mail:zunshen@ukr

\footnotetext{
Abstract. The article covers the legal framework governing the training future Music teachers in Ukraine and China. It was found that in the latter, in addition to setting goals and objectives and the distribution of teaching time, the Ministry of State clearly regulates not only the content of training future music teachers, but also the content of each subject separately. It is established that the education a teacher of music, in addition to pedagogical universities, can be obtained in various educational institutions (colleges, academies, conservatories, institutes, etc.). The goal training future teachers of music in Ukraine and China has been determined, which is very similar.
} 


\section{Інноватика у вихованні. Випуск 13.Том 1. 2021.}

It is investigated that the distribution of disciplines aimed at the formation of general and professional competencies is quite uniform, both in Ukraine and in China. It is established that the difference in the content training future teachers of music is that in China special attention is paid to the study of English, political science, philosophy, history and culture of a particular region (depending on the location of the university), and in Ukraine is much more individual professional classes, which is due to the lack of qualified teachers.

It is determined that in addition to similar for both countries active pedagogical practice, in which students observe the teacher`s work help him, conduct lessons, organize educational activities, communicate and play with children, there are absolutely different. For China, this is an optional social practice, for Ukraine it is a mandatory «Organizational and educational pedagogical practice in children's health and recreation facilities».

It was found that future teachers of both countries are dissatisfied with the large number of general education disciplines and insufficient practical training, but in Ukraine this issue is solved by introducing elements of dual education.

It is outlined that educational work in institutions of higher pedagogical education in China and Ukraine also has common directions and forms.

Keywords: Music teacher, academic disciplines; institutions of higher pedagogical education.

Стаття надійшла до редакиії 05.05.2021 